\title{
Feeling the draft
}

Legislation to control experiments with recombinant DNA is progressing slowly through Congress. Colin Norman reports

THReE months ago, when Congress first began to consider legislation to regulate recombinant DNA experiments in the United States, many scientists were hoping that a straightforward bill, establishing a uniform set of national controls, would swiftly be put together and and passed without too much wrangling. Congress has not obliged, however. When the bill finally emerges, it will be a lengthy and complex document, establishing an elaborate mechanism for setting new regulations, ensuring that they are followed, and providing punishment for those caught flouting the rules. Moreover, a good deal of political manoeuvring is still in store before the bill emerges in final form from the Congressional mill.

At least the legislative machinery is beginning to pick up speed, however. Last week, key committees in both the House and the Senate passed their own versions of legislation, paving the way for consideration of the measures by the full House and Senate in the next few weeks. The House subcommittee on Health, headed by Representative Paul G. Rogers, approved a bill running to 46 pages; it will now be considered by the full Commerce Committee and possibly by the Committee on Science and Technology, before being sent to the House floor. It is unlikely that the draft approved by the health subcommittee will be substantially modified at any of those stages, however. In the Senate, the Committee on Human Resources last week approved a 56-page bill drafted by staff members of the Senate Health subcommittee, headed by Senator Edward Kennedy. It will probably be sent to the full Senate next month.

The two versions differ significantly in their approach to regulating recombinant DNA research, and thus a Senate-House conference committee will eventually be given the sask of putting together a compromise bill.

Though there are substantial differences in the two bills, there are a number of important points of similanity. Both would require new safety regulations to be established, governing all recombinant DNA experiments in the United States. They also both require that facilities in which recombinant DNA experiments are con- ducted must be licenced, that violators be subject to heavy fines, that extensive records be kept, and that federal inspectors have a right to investigate facilities and records. They also call for a study of long-term implications of genetic engineering, and they both come close to specifying that the federal regulations should take precedence over controls imposed by state or local governments. The big difference is that the Senate version would establish a Presidentiallyappointed regulatory commission to draft and enforce the regulations, while the House version would leave much of the day-to-day enforcement to local biohazards committees.

The House bill, though largely written by committee staff members, was put together during three lengthy committee meetings at which about half-a-dozen Congressmen took an active interest. The chief provisions:

- The Secretary of Health, Education and Welfare (HEW) would be required to draft new regulations governing recombinant DNA research. They would prescribe physical and biological containment conditions for different categories of experiments, set out training requirements for laboratory workers and researchers, specify systems to monitor for the escape of potentially hazardous organisms, require medical surveillance of laboratory personnel, and describe reports and records which must be maintained in research facilities. The regulations would have to be published within one year after the bill is passed, and they would come into effect six months later. In the meantime, the NIH guidelines would be made applicable to all recombinant DNA experiments, no matter whether they are conducted in public or private institutions.

- A part-time advisory committee, consisting of 17 members appointed by the Secretary of HEW, would be established to assist in drafting and implementing the regulations. A majority of the members would be people who are not engaged in recombinant DNA research, and the committee would include a laboratory worker and a representative from industry.

The guts of the bill is a provision establishing a mechanism for licencing facilities housing recombinant DNA experiments. An application for a licence would have to contain a thorough description of proposed experiments, including experimental protocols, assurances that the regulations would be followed, and an analysis of the potential risks to public health or the environment arising from each proposed experiment. The application and granting procedure would vary according to the type of experiment proposed, but in every case, local biohazards committees would play a strong rôle.

These would be committees consisting of between 9 and 15 members, including at least one laboratory worker and one local public health official. A majority of the committee members would be scientists. The biohazards committee would review all licence applications for facilities under its purview, and it would have the power to grant licences for experiments requiring low containment levels--P1 and P2 under the NIH guidelines. For research requiring $\mathrm{P} 3$-level containment, the licence application would have to be reviewed first by a biohazards committee, and subsequently by the Secretary of HEW and his advisory committee. The Secretary would be able to override a negative recommendation by his advisory committee, but in practice such a decision would be unlikely. A similar procedure would be required for applications involving P4-level work, but in such cases the Secretary would be able to grant a licence only if his advisory committee recommended approval.

It should be noted that, by specifying different arrangements for experiments requiring $\mathrm{P} 1, \mathrm{P} 2, \mathrm{P} 3$ and $\mathrm{P} 4$ levels of physical containment, the legislation presumes that such levels will form the basis of the final regulations.

The House bill would leave most of the inspeotion of facilities and monitoring to the biohazards committees, though federal inspectors would also be empowered to check to ensure that the regulations are followed. Violations could result in revoking a facility's licence, and in addition researchers could be subject to fines amounting to $\$ 5,000$ per day for each offence. Particularly serious and wilful violations could result in a $\$ 50,000$ fine and up to a year in prison. The bill also provides legal protection for workers who blow the whistle on their employers by bringing incidents of flouting the rules to public attention.

The bill approved by the Senate committee would establish a very different regulatory framework. It would set up an 11-member National Recombinant DNA Safety Regulation Commission to draft regulations, issue licences for facilities and monitor compliance with the regulations. The chairman would be a full-time official, while the other commissioners would be part time; all would be appointed by the President. A majority of the commission members would be non- 
biologists.

The commission would be required to issue new regulations within 120 days after the bill is approved; they must be at least as strict as the $\mathrm{NIH}$ guidelines. The Senate bill also requires that all facilities housing recombinant DNA cxperiments must be licenced, and licence applications must specify the proposed experiments, the names of investigators and their qualifications. The Commission would be responsible for granting all licences, but initial review and approval of recombinant DNA projects would be undertaken by local biohazards committees. At least one third of the members of the local committee must be nonbiologists, and at least another third would be employees of the facility applying for the licence.

The Senate bill also specifies that federal inspectors would have the right to enter facilities to inspect records and equipment. It also requires extensive record-keeping by researchers. As in the House bill, the Senate version specifies that violations could result in denial of a licence, and violators could be subject to a fine of $\$ 10,000$ per day.

Though the two bills would probably not lead to the adoption of radically different regulations, they would lead to different forms of bureaucratic control. In particular, a number of scientists have expressed concern that if a large commission, backed by a fulltime staff, is established to review and approve each licence application, there could be considerable bureaucratic delay. One scientist also suggested last week that a Presidential commission to oversee recombinant DNA research would amount to 'overkill'.

One of the most controversial points in the legislation has been the question of whether federal regulations should override controls imposed by state or local governments. In fact, that was the only point which was even discussed during the Senate committee's consideration of the bill last week. The House and Senate versions are not greatly different in their requirements. The Senate bill would allow local governments to set stricter controls only if the extra safety precautions are "material and relevant" to deal with "health and environmental concerns or comparable compelling local conditions", and if they are not "arbitrary or capricious". The House bill would allow stricter local controls only if the Secretary of HEW determines that they are "necessary to protect public health or the environment".

The bills are not likely to reach the floor of either the Housc or the Senate much before the end of July, and it will then take several weeks for a conference committee to draft a compromise between the two versions.
- An intensive lobbying campaign by space scientists has won a reprieve for two high priority projects, the Large Space Telescope and the Jupiter Orbiter Probe. A key Senate appropriations subcommittee last week voted funds for both projects, in spitc of opposition from Senator William Proxmire, the subcommittee chairman. The vote will almost certainly ensure that the telescope will go ahead as planned, but prospects for the Jupiter project are a little less certain.

The Large Space Telescope seems assured of Congressional support because it has already been approved by the House of Representatives. Last week, the House passed a budget bill for NASA which contains funds to begin building the instrument in the 1978 fiscal year. Thus, if the full Senate follows the recommendation of Proxmire's subcommittee, which is likely, both the House and Senate versions of the NASA budget bill would contain funds for the telescope, thereby virtually guaranteeing final Congressional approval for the project.

The Jupiter Orbiter Probe is still in some trouble, however, because no funds for the project were included in the House bill. The House Appropriations Committee had specifically deleted the money from NASA's budget request, arguing that approval of two major space science projects in one year cannot be justified. The spacc telescope has higher priority, the committee said, and therefore the Jupiter project should be dropped. The full House followed the committee's recommendation.

It thus seems likely that the Senate version of the NASA budget bill will contain funds for the Jupiter project, the House version will not, and the matter will have to be decided by a House-Senate conference committee. NASA is hoping that it can persuade the conference committee to approve the project.

It is likely that the conference committec will in fact provide some funds for the project, but not as much as the $\$ 20.7$ million that NASA requested for 1978. In that case, NASA would at least be able to begin building the spacecraft and it would be able to avoid laying off scientists and engineers at the Jet Propulsion Laboratory, which will manage the project. The spacecraft is scheduled to be launched late in 1981 or early in 1982.

- President Carter's plan to slow down the development of a commercial liquid metal fast breeder reactor is, like other key elements of his energy policy, being severely mauled on Capitol Hill. Carter had proposed that a demonstration brecder reactor, scheduled to be built on the Clinch River in Tennessee, should be deferred indefinitely, and he recommended that virtually all the funds for the project should be deleted from the budget for the Energy $\mathrm{Re}$ search and Development Administration. Last week, however, the House Committee on Science and Technology voted by 19 to 11 to approve the Clinch River plant and it restored $\$ 150$ million to ERDA's budget to begin constructing the facility next year.

The vote far from guarantees that the Clinch River plant will be saved from the axe, but it does at least ensure that there will be a full-scale debate on the matter when the ERDA bill reaches the House Floor. Senator Howard Baker, who represents Tennessee, reportedly said last week that the vote has made him "optimistic for the first time" that the plant will be reprieved.

Carter's recommendation that the Clinch River plant should be cancelled was a key part of his plan to prevent the use of plutonium as a reactor fuel. $\mathrm{He}$ also proposed that the United States should defer indefinitely the reprocessing of spent reactor fuels to recover plutonium for recycle in light water reactors. At the same time, the Administration is trying to dissuade other countries, particularly those which do not possess nuclear weapons, from entering the so-called plutonium econamy.

The House Committee on Science and Technology was persuaded, however, that other countries would not defer their plans to recycle plutonium and build breeder reactors. The committee therefore argued that the United States should not allow itself to be deprived of a technology which other industrialised countries are vigorously pursuing.

Similar statements have also been made by Senator Frank Church, who heads a key energy research subcommittee in the Senate, and by Senator Henry Jackson, who chairs the Senate Committce on Energy and Natural Resources. Their support for the breeder programme is almost certain to force a full debate on the Clinch River plant in the Senate.

Thus a protracted debate on Carter's plutonium policy seems assured in both the House and the Senate. At this stage, nobody is willing to predict the outcome.

Colin Norman 